'Department of Rheumatology. Escuela de Medicina. Pontificia Universidad Católica de Chile. Santiago, Chile. ${ }^{2}$ Department of Public Health. Escuela de Medicina. Pontificia Universidad Católica de Chile. Santiago, Chile.

This study was performed with an unrestricted grant from Conicyt FONIS SA1610087.

The authors declare no conflict of interest in this article.

Recibido el 26 de septiembre de 2018, aceptado el 16 de abril de 2019.

Corresponding author: Josefina Durán jgduran@uc.cl

Angélica Domínguez madominguez@med.puc.cl

\section{Evaluation of the Health Assessment Questionnaire Disability Index in Chilean patients with rheumatoid arthritis}

\author{
JOSEFINA DURÁN ${ }^{1}$, ANGÉLICA DOMÍNGUEZ², MANUEL ESPINOZA²
}

\section{ABSTRACT}

Background: The Health Assessment Questionnaire Disability Index (HAQDI) is one of the main instruments used to evaluate functional status in rheumatoid arthritis (RA). Aim: To assess the reliability and validity of the Spanish version of HAQDI in Chilean RA population. Materials and Methods: The questionnaire was applied to 98 patients with $R A$ aged $44 \pm 12$ years (90\% women). Reliability was assessed using Cronbach's alpha statistic for internal consistency. Construct validity was assessed by comparing total HAQDI value and eight HAQDI domains with multiple parameters of disease activity. Discriminant validity was evaluated by classifying disease activity in low, medium or high and evaluating HAQDI value in each category. Floor and ceiling effects were evaluated. To assess construct validity, principal components analysis was performed using varimax rotation. Results: There were no issues in the comprehensibility of the questionnaire. Mean HAQDI score was $1.57 \pm$ 0.66. Standardized Cronbach's Alpha was 0.883. Correlations between Chilean HAQ domains had a p value less than 0.001, and values ranged from 0.317 to 0.597. Activity parameters, DAS 28 and CDAI were significantly correlated with HAQDI domains. Mean HAQDI values were $0.98 \pm 0.59,1.45 \pm 0.57$, and 1.90 \pm 0.56 for mild, moderate and severe disease activity. A principal components analysis identified two factors that accounted for $70.0 \%$ of total variability. Conclusions: This study shows that the Spanish version of HAQDI is reliable and valid and can be used in Chilean patients with $R A$.

(Rev Med Chile 2019; 147: 612-617)

Key words: Arthritis; Arthritis, Rheumatoid; Disability Evaluation; Quality of Life.

\section{Evaluación del Health Asessment Questionnaire Disability Index (HAQDI) en pacientes chilenos con artritis reumatoide}

Antecedentes: El Health Assessment Questionnaire Disability Index es uno de los principales instrumentos utilizados para evaluar incapacidad funcional en la artritis reumatoide (AR). Objetivo: Evaluar la fiabilidad y validez del HAQDI en la población chilena con AR. Material y Método: El cuestionario fue respondido por 98 pacientes con AR de $44 \pm 12$ años de edad (90\% mujeres). La confiabilidad se evaluó usando la estadística alfa de Cronbach. La validez de 
constructo se evaluó comparando el valor total de HAQDI y de cada uno de sus dominios con múltiples parámetros de actividad de la enfermedad. La validez discriminante se evaluó clasificando la actividad de la enfermedad en bajo, medio $o$ alto y evaluando el valor de HAQDI en cada categoría. Se determinaron efectos de piso y techo. Se realizó un análisis factorial utilizando rotación de varimax. Resultados: El valor promedio del HAQDI fue de 1,57 \pm 0.66 . El alfa estandarizado de Cronbach fue 0,883. Las correlaciones entre dominios de HAQDI tuvieron un valor $p<0,001$ con valores entre 0,317 y 0,597. Los parámetros de actividad se correlacionaron significativamente con los dominios HAQDI. Se encontraron diferencias significativas entre el puntaje de HAQDI en relación con los grados de actividad de la enfermedad. Los valores medios de HAQDI fueron 0,98 $\pm 0,59,1,45 \pm 0,57$ y 1,90 $\pm 0,56$ para actividad leve, moderada $y$ severa, respectivamente. El análisis de componentes principales identificó dos factores que representaron el $70.0 \%$ de la variabilidad total. Conclusiones: $L a$ versión española de HAQDI es confiable y válida en pacientes chilenos con AR.

Palabras clave: Artritis; Artritis Reumatoide; Calidad de Vida.

$\mathrm{R}$ heumatoid arthritis (RA) is a chronic disease that generates functional disability. The functional impairment produced by RA implicates a deterioration in quality of life ${ }^{1,2}$ and it generates important costs ${ }^{3-5}$. The Health Assessment Questionnaire Disability Index (HAQDI) is one of the main instruments used to evaluate functional status in $\mathrm{RA}^{6}$. HAQDI has been shown to be a predictor of work disability and mortality ${ }^{7}$.

A Spanish version of HAQDI was translated and validated by Cardiel et $\mathrm{al}^{8}$. Although this version is widely used in Chile, it has not been validated in Chilean population. The aim of this study was to assess the reliability and validity HAQDI in Chilean RA population.

\section{Materials and Methods}

The Spanish version of the HAQDI was revised by a group of Chilean rheumatologists who concluded that no wording changes were necessary given that language was clear and easy to understand for the Chilean population. This version was backtranslated into English by a bilingual individual. This backtranslated version was identical to the original American version.

Patients with confirmed RA that were asisted at the Red Salud UC-CHRISTUS Rheumatology Clinic in Santiago, Chile, between July 2010 and July 2017 were included for analysis. In each clinical visit a nurse asked subjects to complete the
HAQDI questionnaire, and a global health visual analogue scale (PtGHVAS). A rheumatologist performed a tender joint count (TJC), swollen joint count (SJC) and also completed a global health visual analogue scale (PhGHVAS). Erythrocyte Sedimentation Rate (ESR) was obtained in each visit. The study was approved by the Red Salud UC-CHRISTUS Ethical Committee.

Reliability was assessed using Cronbach's alpha statistic for internal consistency. The criterion of $>.80$ was established as evidence of satisfactory reliability.

Regarding validity, cross-sectional construct validity was assessed by comparing total HAQDI value and each of the eight HAQDI domains with parameters of disease activity (SJC, TJC, PtGHVAS, PhGHVAS and ESR) as well as the disease activity scores (DAS28) and Clinical Disease Activity Index $(\mathrm{CDAI})^{10,11}$. Also, principal components analysis were performed using varimax rotation.

Discriminant validity was evaluated by classifying disease activity in low, medium or high according to established DAS28 cut-off points and evaluating HAQDI value in each category.

Floor and ceiling effects were evaluated and they were considered to be present if at least $15 \%$ of the patients scored 0 (lowest score) or 3 (highest score) respectively.

\section{Statistical Analysis}

Numerical variables are presented as mean \pm standard deviation (SD). Categorical variables are 
presented as count and percentage. All correlations are Spearman Correlations. Coefficients of greater than 0.6 , between 0.6 and 0.3 and less than 0.3 were considered as strong, moderate and weak correlations, respectively ${ }^{11}$.

Differences between HAQDI score in relation to the degrees of disease activity measured by DAS28 were determined by analysis of variance and prior Levene's test for Homogeneity of variances. In the group-to-group comparisons, Tukey's post-hoc tests were used. Patients were split into 3 groups according to disease activity: mild (DAS2 $<<=3.2)$, moderate $(3.2<$ DAS $28<=5.1)$, and severe (DAS28 $>5.1)$.

Statistical analyses were performed using SPSS, version 17.0 (SPSS Inc., Chicago, IL, USA). Statistical significance was set as a p value of 0.05 or less.

\section{Results}

Four out of 102 patients had a percentage of missing response of $25 \%$ or more. All analyses were performed in the remaining 98 patients. The majority of subjects were females $(89.5 \%)$ with a mean \pm SD age of $43.9 \pm 12.3$ years, $23.5 \%$ had less than 12 years of education and $54 \%$ were overweight or obese. There were no issues in the comprehensibility of the questionnaire.

\section{Reliability}

Mean values of each domain are presented (Table 1). Standardized Cronbach's Alpha was of
0.883 and this value was modified up to 0.863 if one domain was deleted.

\section{Validity}

Correlations between Chilean HAQ domains are presented (Table 1). All correlations between domains had a p value $<0.001$, and values ranged from 0.317 to 0.597 . Floor effect appeared in one out of 98 patients and same as ceiling effect.

\section{Disease severity variables}

SJC, TJC, ESR, PtGHVAS, PhGHVAS, DAS28 and CDAI were tested for correlation with the different domains of HAQDI (Table 2). The highest correlation was between DAS28 and Grip domain with a value of $0.571(p<0.001)$. SJC and PhGHVAS did not have a significant correlation with the Walking domain (Table 2).

Significant differences were found between the HAQDI score in relation to the degrees of disease activity ( $\mathrm{p}<0.001$ for global test) and all pairwise comparison had $\mathrm{p}<0.05$ (Figure 1). Mean $\pm \mathrm{SD}$ of HAQDI values were $0.98 \pm 0.59,1.45 \pm 0.57$, and $1.90 \pm 0.56$ for mild, moderate and severe disease activity.

Items were suitable to a principal components analysis (Kaiser-Meyer-Olkin measure of sampling adequacy: 0.869). Two factors accounted for $70.0 \%$ of total variability. The first factor congregates Grip, Eating and Reach items and Walking, Hygiene, Arising and Activities conform the second factor.

Table 1. Description of eight domains of the Chilean HAQ and Correlation matrix for each domain of the Chilean HAQ for $n=98$ patients

\begin{tabular}{|c|c|c|c|c|c|c|c|c|c|}
\hline HAQ Domain & Mean \pm SD & D and $G^{*}$ & Arrising & Eating & Walking & Hygiene & Reach & Grip & Activities \\
\hline $\mathrm{D}$ and $\mathrm{G}^{*}$ & $1.32 \pm 0.86$ & 1.000 & 0.437 & 0.426 & 0.361 & 0.507 & 0.375 & 0.393 & 0.432 \\
\hline Arrising & $1.33 \pm 0.82$ & & 1.000 & 0.411 & 0.597 & 0.533 & 0.547 & 0.526 & 0.532 \\
\hline Eating & $1.58 \pm 0.92$ & & & 1.000 & 0.398 & 0.423 & 0.534 & 0.540 & 0.471 \\
\hline Walking & $1.41 \pm 0.80$ & & & & 1.000 & 0.544 & 0.464 & 0.317 & 0.497 \\
\hline Hygiene & $1.27 \pm 0.91$ & & & & & 1.000 & 0.449 & 0.469 & 0.461 \\
\hline Reach & $1.94 \pm 0.94$ & & & & & & 1.000 & 0.521 & 0.522 \\
\hline Grip & $1.89 \pm 0.80$ & & & & & & & 1.000 & 0.508 \\
\hline Activities & $1.60 \pm 0.94$ & & & & & & & & 1.000 \\
\hline Total HAQ & $1.57 \pm 0.66$ & & & & & & & & \\
\hline
\end{tabular}

*Dressing and Grooming. 
Validación de HAQDI en pacientes chilenos con artitis reumatoide - J. Durán et al

Table 2. Spearman correlation coefficients between each domain and the Chilean HAQ and outcomes of rheumatoid arthritis disease activity for $n=98$ patients

\begin{tabular}{|lccccccc|}
\hline Chilean HAQ domain & SJC & TJC & PGHVAS & PhGHVAS & CDAI & ESR & DAS28 \\
\hline Dressing and Grooming & $0.431^{* *}$ & $0.523^{* *}$ & $0.515^{* *}$ & $0.300^{* *}$ & $0.526^{* *}$ & 0.180 & $0.484^{* *}$ \\
\hline Arising & $0.317^{* *}$ & $0.498^{* *}$ & $0.409^{* *}$ & $0.316^{* *}$ & $0.468^{* *}$ & $0.443^{* *}$ & $0.520^{* *}$ \\
\hline Eating & $0.223^{*}$ & $0.378^{* *}$ & $0.411^{* *}$ & 0.119 & $0.347^{* *}$ & 0.195 & $0.486^{* *}$ \\
\hline Walking & 0.189 & $0.335^{* *}$ & $0.405^{* *}$ & 0.084 & $0.299^{* *}$ & $0.310^{* *}$ & $0.423^{* *}$ \\
\hline Hygiene & $0.312^{* *}$ & $0.379^{* *}$ & $0.253^{*}$ & $0.302^{* *}$ & $0.371^{* *}$ & 0.190 & $0.343^{* *}$ \\
Reach & $0.242^{*}$ & $0.400^{* *}$ & $0.348^{* *}$ & 0.099 & $0.356^{* *}$ & $0.355^{* *}$ & $0.520^{* *}$ \\
\hline Grip & $0.369^{* *}$ & $0.483^{* *}$ & $0.373^{* *}$ & $0.264^{* *}$ & $0.478^{* *}$ & $0.307^{* *}$ & $0.571^{* *}$ \\
\hline Activities & $0.232^{*}$ & $0.371^{* *}$ & $0.411^{* *}$ & 0.137 & $0.340^{* *}$ & $0.241^{*}$ & $0.406^{* *}$ \\
\hline Chilean HAQ & $0.357^{* *}$ & $0.529^{* *}$ & $0.503^{* *}$ & $0.236^{*}$ & $0.500^{* *}$ & $0.373^{* *}$ & $0.608^{* *}$ \\
\hline
\end{tabular}

${ }^{* *} p$ values $<0.001 ;{ }^{*} p$ values $<0.005$.

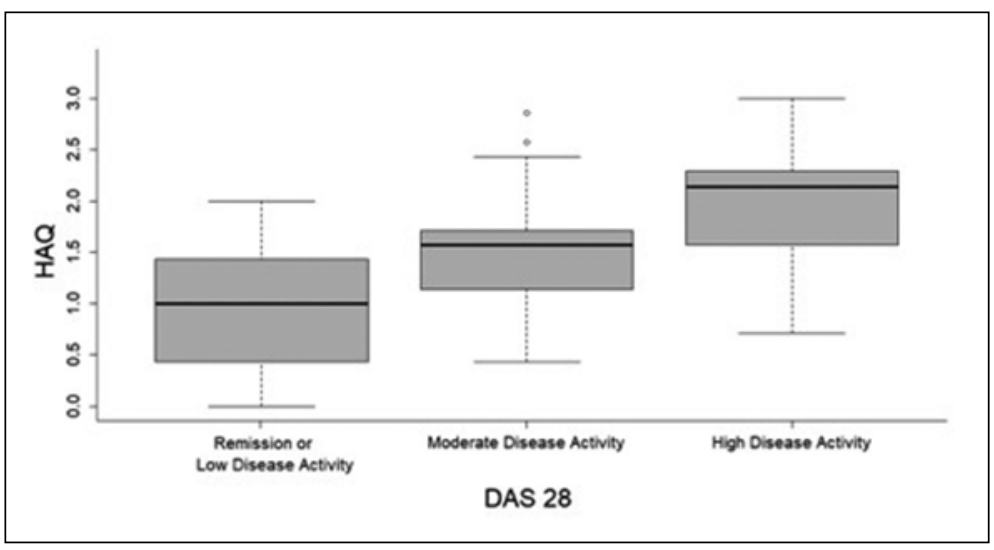

Figure 1. Discriminant Validity of $\mathrm{HAQ}$ $\mathrm{DI}$ in relation to RA disease activity. HAQ values in different levels of disease activity: remission or low disease activity (DAS28 < = 3.2), moderate disease activity $(3.2<$ DAS $28<=5.1)$, and high disease activity (DAS $28>5.1$ ).

\section{Discussion}

In Chile the Spanish version of HAQDI is applied in clinical practice but to date no evidence existed it would have the same validity that had been shown in other countries ${ }^{12-17}$. Our study shows that the HAQDI Spanish version is reliable in Chilean RA population. We evaluated reliability, construct validity and discriminant validity and found it is a valid instrument to be used in this population. No floor or ceiling effects were identified.

The non-significant correlation between SJC and the walking item of HAQDI can be partly explained because the 28 joint count defined for DAS28 and CDAI does not include feet joints.
Therefore, SJC does not necessarily reflect feet inflammation ${ }^{19}$. A low correlation between these two items has also been identified in previous studies. The other variable that did not have significant correlations with all items of HAQDI was the PhGHVAS. Given the subjectivity if this item it is possible that physicians in Chile underestimate the limitations patients experience. Further, the strongest correlations were seen with CDAI and DAS28 activity scores that are validated instruments to measure disease activity and are what conduct therapeutical decisions ${ }^{9,10}$. Regarding total HAQDI score all correlations were significant and were similar to correlations found in validation studies performed in other countries ${ }^{12,13,17,18}$. We found functional impairment in 
RA measured by total HAQDI was directly related to disease activity.

In addition, factorial analysis identified two factors which is an adequate finding and particularly considering the affection of small versus large which may compromise different functions.

Given the importance of having consecutive measures of disease activity and impairment of RA patients the findings of this study are highly relevant for our clinical practice. HAQDI in its Spanish version is required by the Chilean Ministry of Health as a follow up measurement in all subjects that are receiving government funded biologics treatments ${ }^{20}$.

A limitation of this study is that the sample had a higher educational level than Chilean general population according to the 2017 National Health Survey in which $78 \%$ had less than 12 years of formal education ${ }^{21}$. Therefore, to conclude that the results of this study may be the same applied to the general population is uncertain. However, there were no comprehension problems in subjects with low educational level in our sample.

Also test-retest as a measure of reliability was not performed, which is an important measure of reliability.

HAQDI is key as a prognostic and follow up measure used in RA. We have shown HAQDI represents a valid instrument to be used among Chilean RA patients.

\section{References}

1. Matcham F, Scott IC, Rayner L, Hotopf M, Kingsley $\mathrm{GH}$, Norton S. The impact of rheumatoid arthritis on quality-of-life assessed using the SF-36: a systematic review and meta-analysis. Semin Arthritis Rheum 2014; 44: 123-30.

2. Chorus, AMJ, Miedema HS, Boonen A, Van Der Linden S. Quality of Life and Work in Patients with Rheumatoid Arthritis and Ankylosing Spondylitis of Working Age. Ann Rheum Dis 2003; 62: 1178-84.

3. Pincus T, Callahan LF, Sale WG, Brooks AL, Payne LE, Vaughn WK. Severe functional decline, work disability and increased mortality in seventy-five rheumatoid arthritis patients studied over nine years. Arthritis Rheum. 1984; 27: 864-72.

4. De Croon EM, Sluiter JK, Nijssen TF, Dijkmans B, Lankhorst G, Frings-Desen M. Predictive factors of work disability in rheumatoid arthritis: a systematic literature review. Ann Rheum Dis 2004; 63: 1362-67.
5. Allaire S, Wolfe F, Niu J, Lavalley M. Contemporary Prevalence and Incidence of Work Disability Associated with Rheumatoid Arthritis in the US. Arthritis Rheum 2008; 59: 474-80.

6. Maska L, Anderson J, Michaud K. Measures of Functional Status and Quality of Life in Rheumatoid Arthritis. Health Assessment Questionnaire Disability Index (HAQ), Modified Health AssessmentQuestionnaire (MHAQ), Multidimensional Health Assessment Questionnaire (MDHAQ),Health Assessment Questionnaire II (HAQ-II), Improved Health Assessment Questionnaire(Improved HAQ), and Rheumatoid Arthritis Quality of Life (RAQoL). Arthritis Care Res 2011; 63: S4-S13.

7. Farragher TM, Lunt M, Bunn DK, Silman A, Symmons D. Early functional disability predicts both all-cause and cardiovascular mortality in people with inflammatory polyarthritis: results from the Norfolk Arthritis Register. Ann Rheum Dis 2007; 66: 486-92.

8. Cardiel MH, Abello-Banfi M, Ruiz-Mercado R, Alarcon-Segovia. How to measure health status in rheumatoid arthritis in non-English speaking patients: validation of a Spanish version of the Health Assessment Questionnaire Disability Index (Spanish HAQ-DI). Clin Exp Rheumatol 1993; 11: 117-21.

9. Prevoo MLL, van't Hof MA, Kuper HH, Prevoo MLL, van't Hof MA, Kuper HH, et al. Modified disease activity scores that include twenty-eight joint count. Development and validation in a prospective longitudinal study of patients with rheumatoid arthritis. Arthritis Rheum 1995; 38: 44-8.

10. Gaujoux-Viala C, Mouterde G, Baillet A, Claudepierre P, Fautrel B, Le Loët X, et al. Evaluating disease activity in rheumatoid arthritis: which composite index is best? A systematic literature analysis of studies comparing the psychometric properties of the DAS, DAS28, SDAI and CDAI. Joint Bone Spine 2012; 79 (2): 149-55.

11. Hinkle DE, Wiersma W, Jurs SG. Applied Statistics for the Behavioral Sciences. 5th Edition, 2003. Houghton Mifflin. Boston, Mass.

12. Esteves-Vives J, Batlle-Gualda E, Reig A. Spanish version of the health assessment questionnaire. Reliability, validity and transcultural equivalency. J Rheumatol 1993; 20: 2116-22.

13. Citera G, Arriola MS, Maldonado-Cocco JA, Rosemffet MG, Sánchez MM, Goñi MA, et al. Validation and Crosscultural Adaptation of an Argentine Spanish Version of the Health Assessment Questionnaire Disability Index. J Clin Rheumatol 2004; 10: 110-5.

14. Ranza R, Marchesoni A, Calori G, Bianchi G, Braga M, Canazza S, et al. The Italian version of the functional disability index of the health assessment questionnaire. 
A reliable instrument for multicenter studies on rheumatoid arthritis. Clin Exp Rheumatol 1993; 11: 123-8.

15. Ekdohl C, Eberhardt K, Anderson SI, Svensson B. Assessing disability in patients with rheumatoid arthritis. Use of the Swedish version of the Stanford health assessment questionnaire. Scand J Rheumatol 1988; 17: 263-71.

16. Siegert CE, Vlerning LJ, Vandenbroucke JP, Cats A. Measurement of disability in Dutch rheumatoid arthritis patients. Clin Rheumatol 1984; 3: 305-9.

17. Osiri M, Wongchinsri J, Ukritchon S, Hanvivadhanakul P, Kasitanon N, Siripaitoon B. Comprehensibility, reliability, validity, and responsiveness of the Thai version of the Health Assessment Questionnaire in Thai patients with rheumatoid arthritis. Arthritis Res Ther 2009; 11: R129.
18. Islam N, Baron Basak T, Oudevoshaar MAH, Ferdous N, Rasker JJ, Atiqul Haq S. Cross-cultural adaptation and validation of a Bengali Health Assessment Questionnaire for use in rheumatoid arthritis patients. Int Journal of Rheum Dis 2013; 16: 413-7.

19. Wechalekar MD, Lester S, Proudman SM, Cleland LG, Whittle SL, Rischmueller M, Hill CL. Active foot synovitis in patients with rheumatoid arthritis: applying clinical criteria for disease activity and remission may result in underestimation of foot joint involvement. Arthritis Rheum 2012; 64: 1316-22.

20. http://www.minsal.cl/wp-content/uploads/2018/03/ Protocolo-Artritis-Reumatoide.pdf.

21. https://www.minsal.cl/wp-content/uploads/2017/11/ ENS-2016-17_PRIMEROS-RESULTADOS.pdf. 